\title{
Apartheid South Africa's Participation in United Nations-Organised International Environmental Initiatives in the 1970s: A Reassessment
}

\section{Phia Steyn \\ University of Stirling}

\begin{abstract}
This article focuses on apartheid South Africa's participation in United Nations-organised international environmental initiatives in the 1970 s in order to reassess contemporary and historiographical views that the country was an extremely reluctant participant in UN-led environmental initiatives in the 1970 s because it threatened the country's policy of uncontrolled economic growth and promoted the environment as a political issue, and because the country was not allowed to participate in many of these UN initiatives owing to its isolation within this world body. Utilising archival evidence this article clearly demonstrates that the processes whereby the country decided whether or not to participate in specific UN-organised international environmental initiatives in the 1970s were very complex and conflicting, and in general did not result from a lack of governmental commitment to address the country's multiple environmental challenges. The main argument of this article is that South Africa's limited participation in UN-organised international environmental initiatives in the 1970s resulted from two reasons, namely the mutual distrust between the country and the UN which reached new lows as the 1970s progressed, and the prevailing South African foreign policy strategy of deliberately keeping a low profile in order to avoid confrontation on the international stage
\end{abstract}

Keywords: South Africa, United Nations, UNEP, UNCHE, apartheid, 1970s.

Apartheid South Africa's fraught relationship with the United Nations (hereafter UN) between 1946 and 1994 is a well-documented field in which scholars have charted the gradual decline of the UN's once proud founding member state to the status of international pariah. Much of the literature, however, remains trapped in a narrow treatment of the South African side of this relationship: while most authors focus in some detail on opposing views 
and positions within the UN on how to deal with apartheid South Africa, the country itself is normally presented as a monolith in which the dominant white population, headed by their National Party (hereafter NP) government, formed a united, single entity. ${ }^{1}$ The South African government archives, however, show that this image of unity in purpose and views, especially where government departments dealing with UN-organised international environmental matters in the 1970 s are concerned, obscures the real political differences that existed between government departments as well as the political processes involved in reaching the point where South African delegations were able to take their seats behind the designated South African name plate at international meetings.

The limited historiography on South Africa's participation in UN-led and -organised international environmental initiatives, which started in earnest with the politically significant United Nations Conference on the Human Environment (hereafter UNCHE, held in Stockholm in 1972), also falls victim to this narrow view of South Africa's interaction with global political actors in the 1970s. Scholars have generally failed to address the politicking behind the scenes between the Department of Planning, the main government department concerned with environmental matters, and the Department of Foreign Affairs, the gatekeepers between South Africa and a hostile world. As a result, the limited historiography confirms contemporary views that South Africa was an extremely reluctant participant in UN-organised global environmental initiatives, because the new environmental agenda promoted by the global environmental movement threatened uncontrolled economic growth in the country and promoted the environment as a political issue. What little role the country played was also quickly curtailed by the isolation of South African within the UN in the 1970s, which in turn meant that the country was not allowed to participate in the activities of the newly established United Nations Environment Programme (hereafter UNEP) ${ }^{2}$ from the

\footnotetext{
${ }^{1}$ See, for example, Newell M. Stultz, 'The Apartheid Issue at the General Assembly: Stalemate or Gathering Storm?', African Affairs, 86, 342 (1987), 25-45; M. El-Khawas, 'The Third-World Stance on Apartheid: The UN Record", Journal of Modern African Studies, 9 (1971), 443-52; O.A. Özgür, Apartheid. The United Nations and Peaceful Change in South Africa (New York 1981); James Barber and John Barratt, South Africa's Foreign Policy: The Search for Status and Security 1945-1988 (Johannesburg 1990). Exceptions include Deon Geldenhuys, The Diplomacy of Isolation: South African Foreign Policy Making (Johannesburg 1984).

${ }^{2}$ UNEP was created by the UN General Assembly in December 1972 to be an overarching programme of policy co-ordination. Headquartered in Nairobi, Kenya, it consisted of four parts: a small Environmental Secretariat, responsible for the day-to-day work of the UN in the environmental field which would also serve as a focal point for UN environmental actions and co-ordination; a 54-member Governing Council for Environmental Programmes that formed the central intergovernmental organ for international co-operation on environmental issues; an Environmental Fund to which governments would contribute on a voluntary basis and which would pay for all or part of the new environmental initiatives undertaken by the UN, and an Environment Coordination Board responsible for general co-ordination of the work of the UN agencies in regard to the
} 
end of 1973 onwards, and the numerous UN- organised international environmental initiatives that followed. ${ }^{3}$ Even the official UN narrative supports this narrow view by claiming in its substantial volume documenting the organisation's relationship with apartheid South Africa between 1946 and 1994 that the country was 'effectively excluded from all the organs' of the UN by $1975 .^{4}$

The South African government archives, however, do not support this over-simplified view. The purpose of this article is therefore to reassess South Africa's participation in UN-led international environmental initiatives in the 1970s by incorporating new archival evidence into the existing literature in order to provide a more balanced and comprehensive view of this topic. It focuses solely on the 1970s since UNCHE placed the environment permanently on international political agendas and directly led to a plethora of new global environmental initiatives in this decade, many of which were initiated and led by UNEP. The cut-off date is 1980 since this is the year in which dedicated documentation on UNEP and international environmental conventions and conferences comes to an abrupt end in the South African government archives. ${ }^{5}$ The theme is treated in four sections: it starts with a brief summary of South Africa's relationship with the UN between 1946 and the 1970s, and the country's isolation internationally in the 1960s and 1970s, before proceeding to address the country's participation in UNCHE in 1972, and UNEP between 1973 and 1980, as well as its involvement in UN-organised international environmental conventions and conferences in the 1970s. ${ }^{6}$

environment. John McCormick, The Global Environmental Movement: Reclaiming Paradise (London 1989), 106; United Nations, Report of the United Nations Conference on the Human Environment, Stockholm, 5-16 June 1972, available at: 〈http://www.unep.org/Documents.Multilingual/Default.asp?DocumentID=97> (accessed 20 July 2011).

${ }^{3}$ Phia Steyn, 'Environmental Management in South Africa: Twenty Years of Governmental Response to the Global Challenge, 1972-1992', Historia, 46, 1 (May 2001), 25-53; Phia Steyn and André Wessels, 'The Emergence of New Environmentalism in South Africa, 1988-1992', South African Historical Journal, 42 (May 2000), 210-32; Interviews with James Clarke, Johannesburg, 5.3.1998, and R.F. Fuggle, Cape Town, 26.3.1998.

${ }^{4}$ United Nations, United Nations and Apartheid (New York, 1994), 30.

${ }^{5}$ Presumably these files are still part of the working documents of the Department of Environmental Affairs and Tourism, and not yet available for public consultation.

${ }^{6}$ Readers should note that three main 'actors' in the processes to be discussed are the Secretary for Foreign Affairs, which office was filled by Brand Fourie during the whole period under discussion, and the Secretary for Planning (from February 1973 Planning and the Environment), which position was filled by Dr Piet Rautenbach until February 1976 and thereafter by J.F. Otto. The position of Secretary for Foreign Affairs, for example, within the South African governmental structures in the 1970s refers to the highest-ranking civil servant within the Department of Foreign Affairs, and not to the Minister for Foreign Affairs. The term 'Secretary' was replaced in 1980 with 'Director-General'. 
The main arguments of this article are twofold: firstly that the mutual distrust between the South African government and the UN had a profound impact on the country's participation in many global environmental initiatives in the 1970s, since many of these initiatives were organised by the UN and its agencies. This in turn meant that the South African cabinet and Department of Foreign Affairs were negatively predisposed to the country's participation in UN-led global environmental initiatives despite the enthusiasm of the Department of Planning and the real commitment made by the government to environmental matters in the early 1970s. Secondly, the prevailing South African foreign policy of deliberately keeping a low profile in order to avoid confrontation on the international stage, meant that the country chose to withdraw from many UN-organised international environmental initiatives in the 1970s and were not at least initially excluded from these international environmental initiatives as was claimed by the apartheid government.

\section{$* * *$}

South Africa had a very strained relationship with the United Nations that lasted roughly from 1946, when India lodged a complaint against the treatment of Indians in South Africa at the first session of the General Assembly, until the inauguration of the first freely elected, multiracial African Nationalist Congress government in 1994. Two issues dominated the political agenda where South Africa was concerned in the UN: the domestic policy of apartheid that discriminated against all people of colour solely on the basis of their colour, and South Africa's refusal to grant South West Africa (now Namibia) independence. Even though opposition to South Africa in the UN was limited for the first 14 years, compared to the hostility that followed the violent suppression of the anti-pass march in Sharpeville in 1960, relations were already so strained by the mid-1950s that the country withdrew from the UN Educational, Scientific and Cultural Organisation (hereafter UNESCO) in 1955 and the UN General Assembly on 27 November 1956 in reaction to sustained attacks on the country's race policies. ${ }^{7}$ Thereafter the country maintained only a token representation at the UN until active participation was restored on 24 September 1958 after the '...government was

\footnotetext{
${ }^{7}$ H.H.H. Biermann (ed.), The Case for South Africa as Put Forward in the Public Statements of Eric H. Louw, Foreign Minister of South Africa (New York, 1963), 19, 21, 33, 41; United Nations, The United Nations and Apartheid, 8-20. South Africa was not the only country that found relations with UNESCO challenging at times. The United States and Britain, for example, both withdrew from the agency in 1984 and 1985 respectively on the grounds that it had strayed too far from its founding constitution. For more detail, see Sagarika Dutt, 'The Role of Intellectuals and Non-Governmental Organisations in Britain's Relations with UNESCO', The Round Table, 88, 359 (April 1999), 207-228.
} 
impressed by the more conciliatory attitude adopted towards South Africa in the debates [in 1957], also by delegations which in past years had shown little sympathy for South Africa's point of view'. ${ }^{8}$ This conciliatory attitude was short-lived and after the Sharpeville massacre international opposition to the apartheid government, collectively called the anti-apartheid movement, quickly gained ground and resulted within the UN in the creation of a Special Committee on Apartheid in 1962 and the UN Trust Fund for South Africa in 1965. The first call for economic and diplomatic sanctions against the country was made by the UN General Assembly in 1962, and was followed in 1963 by a call from the Security Council for an arms embargo and the General Assembly recommendation in 1965 of mandatory sanctions.

While these calls for sanctions fell well short of the widespread desire for mandatory sanctions imposed by the Security Council, many individual UN member states started to impose economic, diplomatic, travel, sport and cultural sanctions against the country and agitated within the UN for stronger sanctions on a regular basis. Specialised UN agencies took the lead, especially during the 1960s when the Security Council was not yet ready to make radical decisions where SA was concerned, and the country was expelled from the Food and Agriculture Organisation (1963), the International Labour Organisation (1964) and the World Health Organisation (1964), and excluded from the Economic Commission for Africa from 1963. By 1973 relations with the UN had become sufficiently strained for the General Assembly to adopt the International Convention on the Suppression and Punishment of the Crime of Apartheid on 30 November 1973, and in the following year the country's participation in the organisation came to a standstill when South Africa was expelled from the General Assembly. Full expulsion from the UN, however, was not realised owing to the veto of Britain, the USA and France, when the issue came up for a vote in the Security Council on 24 October $1974 .^{9}$

The strong opposition of the ruling National Party (NP) government in South Africa to the UN by the 1970s was perhaps, given this background, not surprising. In an interview with his biographer in 2004, Pik Botha, who was the South African Ambassador to the UN and to the United States of America in 1974, succinctly summarised the general NP view of the UN at

\footnotetext{
${ }^{8}$ Eric Louw, statement to the $13^{\text {th }}$ session of the General Assembly, 24.9.1958, in Biermann (ed.), The Case for South Africa, 42.

${ }^{9}$ Geldenhuys, Diplomacy of Isolation, 206-7; Kenneth W. Grundy, South Africa: Domestic Crisis and Global Challenge (Boulder 1991), 79; George W. Shepherd, Anti-Apartheid: Transnational Conflict and Western Policy in the Liberation of South Africa (Westport 1977), 128; Barber and Barratt, South Africa's Foreign Policy, 52, 164-70; Theresa Papenfus, Pik Botha and His Times (Pretoria 2010), 147.
} 
the time thus: '[The UN] was seen as an unyielding, emotionally charged organisation that was out to push the whites in South Africa under. Anything with a whiff of the UNO was anathema in NP circles'. ${ }^{10}$ The same also holds true for the UN: in the wake of the 1976 Soweto Uprisings and the violent suppression of these unrests and the death of Steven Biko at the hands of the apartheid police, the UN Security Council passed resolution 418 on 4 November 1977 which finally imposed a mandatory arms embargo against South Africa. After 29 long years the world at large had finally come to agree that apartheid was a threat to international peace and security. ${ }^{11}$

$$
* * *
$$

It was within this context that South Africa participated in UN-organised global environmental initiatives that started with UNCHE in 1972. And, unfortunately for the Department of Planning and all those concerned with the environment in South Africa, the Department of Foreign Affairs acted as very effective gatekeepers between the country and an increasingly hostile outside world. The chief gatekeeper was Brand Fourie, ${ }^{12}$ the Secretary for Foreign Affairs, who exercised very tight control over his department, delegated very little authority and was not known for being innovative. As Geldenhuys notes, this was at least partly due to 'his legendary caution, a characteristic so strong that it tended to stifle innovation and imagination over a wide front in the Department'. ${ }^{13}$ Fourie's cautious style permeated throughout the whole Department of Foreign Affairs and by the 1970s the country's diplomats went out of their way not to draw unwanted attention to the country and its racial policies, even if this meant self-isolation. This approach to international relations would have far-reaching consequences for South Africa's participation in UN-organised international environmental initiatives in the 1970s, as will be discussed.

\footnotetext{
${ }^{10}$ Papenfus, Pik Botha and His Times, 127.

11 United Nations Security Council Resolution 418, 4.11.1977, available at: <http://www.un.org/documents/sc/res/1977/scres77.htm> (accessed 20 July 2011). See also United Nations, The United Nations and Apartheid for a very large selection of documents detailing the strenuous relationship between the UN and South Africa during the apartheid era.

${ }^{12}$ By the 1970s Fourie was regarded as the doyen of all Secretaries. He joined the diplomatic service in 1938, was appointed Secretary for Foreign Affairs in 1966 and as ambassador to the United States of America in 1982. He served a three year term as ambassador before returning to the country to head the South African Broadcasting Corporation from 1985 until 1989. For more details on Fourie, see for example, Geldenhuys, Diplomacy of Isolation; Brand Fourie, Brandpunte: Agter die Skerms met Suid-Afrika se Bekendste Diplomaat (Cape Town 1991).

${ }^{13}$ Geldenhuys, Diplomacy of Isolation, 123.
} 
It seems that South African came late to the UNCHE party. The first reference to this important event within the documentation of the Department of Planning occurs only on 26 February 1971 in a memo written by J. Claassen, the Chief Director of the Department of Planning. In this Claassen noted that seen from a global perspective, UNCHE might serve a very good purpose. However, with the massive rallies against the Springbok rugby tour to Britain in 1969/70 still fresh in the mind, he did note that problems might occur and that the conference had the potential to become a platform for attacks against South Africa. He singled out two issues that had the potential to become problematic: firstly, the Declaration on the Human Environment, since it sought to regulate the relationship not only between individuals, but more importantly between the state and individuals, and secondly, the focus on physical planning and patterns of population settlement. ${ }^{14}$

From the sources consulted, it is unclear to what extent the Department of Planning really viewed these and other potential political problems associated with South Africa's participation at UNCHE as problematic, or if they merely paid lip service to the Department of Foreign Affairs and cabinet's preoccupation with not drawing unwanted attention to the country's apartheid policies. The threat of potential political problems, however, in no way dissuaded those dealing with UNCHE in the Department of Planning from their view that South Africa should attend the conference, and that the delegation should be led by scientific and policy experts from their department. ${ }^{15}$ This much was made clear, for example, in a subsequent memo written by Claassen in which he set out the reasons for and the organisation of UNCHE, and recommended that cabinet approval be obtained for South Africa's participation in this important international event. ${ }^{16}$

\footnotetext{
${ }^{14}$ South African National Archives (Pretoria, hereafter SAB), DCD 2422 27/3/2, Vol. 1: J. Claassen, Chief Director, Department of Planning, 26.2.1971 (memorandum).

15 In the initial years, after assuming responsibility in 1972 for the overall coordination of environmental conservation in South Africa, the Department of Planning, was mostly staffed by planning and policy experts. Expertise in the environmental sciences was provided by other state departments (e.g. Health, Forestry, Agriculture), state and semi-state institutions (e.g. National Parks Board, Council for Scientific and Industrial Research), and the non-governmental environmental sector (especially the Habitat Council which united almost all NGOs within a single organisation on government's urging). Most of these role players were represented on the Cabinet Committee on Environmental Conservation and the advisory South African Committee on Environmental Conservation (renamed Council for the Environment in 1975), both created in 1972, and chaired by the Department of Planning and the Environment. Archive for Contemporary Affairs (hereafter ACA, University of the Free State, Bloemfontein, South Africa), I36.9: J.J. la Grange, 'Die Stand van Omgewingsbewaring op die Nasionale Vlak', paper read at the International Symposium on Planning for Environmental Conservation, Pretoria, 4-6.9.1973; I33.51: J.J. Loots, Minister of Planning and the Environment, Opening Address to the Annual Meeting of the Habitat Council, Durban, 3.4.1975.

${ }^{16}$ SAB, DCD 2422 - 27/3/2, Vol. 1: Memorandum: J. Claassen, Chief Director, Department of Planning, 10.5.1971 (memorandum). See also J.L. Botha, Department of Planning, 12.5.1971 (memorandum).
} 
Piet Rautenbach, ${ }^{17}$ the Secretary for Planning, strongly supported this step and became the chief advocate for the country's participation in UNCHE in negotiations with the Department of Foreign Affairs, from whom permission had to be obtained first before the cabinet would even consider the matter. Fourie, the Secretary for Foreign Affairs, did not share this initial enthusiasm for UNCHE. In a personal discussion following an official request in June 1971 by Rautenbach for permission for a South African delegation to attend UNCHE, Fourie informed him that in his view the country would not be welcome at the conference and consequently should rather not attend. Rautenbach took a few months to react to Fourie's view, and in September 1971 replied by carefully setting out the scientific importance of the conference for the country and the potential benefits that could be obtained from attending. ${ }^{18}$ He did acknowledge the possibility that political problems might occur, but in his view these were clearly outweighed by the potential of UNCHE to allow South Africa to play an even more active role in global environmental initiatives, especially given the fact that the country was the most technologically advanced in Africa. All this led him to conclude that in this particular case we should probably swallow our pride and participate'. ${ }^{19}$ Fourie finally came round to this view after a visit to New York and the UN in September and October 1971 where he discussed UNCHE with the South Africa's Permanent Representative at the UN, C.F.G. von Hirschberg, and representatives from numerous other countries. These discussions led him to conclude in a letter to Rautenbach that

the general impression that I obtained was that what is aimed at with this conference, is indeed a purely scientific conference of the highest quality... In light of this... I want to withdraw my original reservation

\footnotetext{
${ }^{17}$ Rautenbach was an exceptionally gifted bureaucrat who became the first serving civil servant to be awarded the Decoration for Outstanding Service in 1980. He was also honoured with the SA Police Star for Outstanding Service in 1981. He made his name in the 1960s when he was tasked with implementing the economic decentralisation theories that was intended to underpin the viability of black homelands, and also took the lead in the Lilongwe project in Malawi. He was promoted to Secretary of Planning in 1970 and served in this role until 1 February 1976 when he was appointed to the Public Service Commission (later renamed the Commission for Administration). He chaired the commission from August 1976 and was responsible for planning and implementing the drastic state reorganisation and rationalisation plans initiated by P.W. Botha. He continued to serve in high-ranking civil service and other governmental positions well after his official retirement in 1981. For details on Rautenbach, see for example, 'Lief vir Mense en Stories', Suid-Afrikaanse Oorsig, 1.2.1980; "n Voorste Riemlander Tree Af met Polisiester', Rapport, 29.11.1981. Readers should note that it has not been possible to locate Rautenbach's personal papers in any of the archival depositories in South Africa.

${ }^{18}$ Rautenbach emphasised in particular the opportunity to learn from experts from other countries, to exchange and cooperate with other countries on scientific and technical matters, and observeobserving $[=$ observe $]$ firsthand the planning of future UN environmental priorities and actions.

${ }^{19}$ SAB, DCD 2422 - 27/3/2, Vol. 1: Secretary for Planning - Secretary for Foreign Affairs, 7.9 .1971 (letter). See also Secretary for Planning - Minister of Planning, Verenigde Nasie Konferensie oor die Menslike Omgewing in Stockholm: 5 tot 16 Junie 1972, 18.11.1971 (memorandum).
} 
and want to express the opinion that it will be desirable that South Africa be represented at the conference. $^{20}$

Having finally obtained the necessary permission from the Department of Foreign Affairs, Rautenbach's last hurdle was the cabinet, and much to his surprise they were initially not very positive about the country's participation in UNCHE, despite the approval of the Department of Foreign Affairs. Rautenbach's memorandum to the Minister of Planning of 18 November 1971 was returned on 6 December with a note from the minister that informed Rautenbach that the cabinet had not managed to deal with this request at their meeting of 3 December. He proceeded to say that he 'spoke with all the relevant ministers after today's meeting and they feel that in view of the current drive towards financial savings it is not necessary that this conference be attended'. ${ }^{21}$ This negative response led Rautenbach to change tactics, and whereas he, in his original submission to the minister, had set out the long process of obtaining permission from Foreign Affairs for UNCHE attendance and the preparations taken since then, along with the general importance of the conference, he now directed attention to just how the conference directly aligned with government policy and interests. He focused in particular on four issues: firstly, that South Africa had a long and proud record of international cooperation in scientific and technical fields. ${ }^{22}$ Confronted with the need to rethink its relationships with African countries set to become independent soon, the country committed itself in 1957 to greatly expand its international cooperation with African countries on scientific, technical and economic issues. In Rautenbach's view UNCHE clearly offered the opportunity to do just that. ${ }^{23}$ Secondly, the pollution report that was submitted to the cabinet early in 1971 (before attending UNCHE became an issue) made it clear that there existed great concern over and interest in combating pollution in South Africa. As a result, both the public and private sectors would be very disappointed if the country did not attend

\footnotetext{
${ }^{20}$ SAB, DCD 2422 - 27/3/2, Vol. 2: Secretary for Foreign Affairs - Secretary for Planning, 15.10.1971 (letter). 21 SAB, DCD 2422 - 27/3/2, Vol. 2: Secretary for Planning - Minister of Planning, Verenigde Nasie Konferensie oor die Menslike Omgewing in Stockholm: 5 tot 16 Junie 1972, undated, 1-2 (memorandum). South Africa experienced a brief deficit on its Balance of Payments on current account between 1971 and mid1972, hence the need for financial savings. D. Hobart Houghton, The South African Economy (4 ${ }^{\text {th }}$ edition, Cape Town, 1976), 240-1.

${ }^{22}$ For more detail on South Africa's participation in international intellectual networks and exchanges see, for example, Saul Dubow, A Commonwealth of Knowledge: Science, Sensibility and White South Africa 1820-2000 (Oxford, 2006).

${ }^{23}$ In 1957 the Minister of Foreign Affairs, Eric Louw, expressed the hope that the country's economic and scientific power could make South Africa a 'permanent link between the Western nations on the one hand and the population of Africa south of the Sahara on the other hand'. As Barber and Barratt note, through this process of co-operation on technical, scientific and economic matters, the apartheid government had hoped that African states would come to realise that apartheid was not a threat to them. Barber and Barratt, South Africa's Foreign Policy, 38 (includes Eric Louw quote).
} 
UNCHE. $^{24}$ Thirdly, sea pollution, which the cabinet had decided was important to South Africa, would be discussed and decisions would be made on this crucial matter. ${ }^{25}$ Fourthly, while it was by then too late to arrange for South African delegates to make actual presentations at UNCHE, the conference would still afford the country the opportunity to disseminate publications and statements, and to hold discussions with delegates from countries that were not hostile towards the republic. As a small concession to the official reason for rejecting participation in UNCHE, Rautenbach did state that if financial savings really were an important factor for the cabinet, then the delegation would limit its size, which would reduce its costs. ${ }^{26}$ Cabinet permission was finally granted in March 1972, and on 7 March the Minister of Planning, J.J. Loots, was able to issue a press release that announced that South Africa would attend UNCHE because the country had a 'current interest' in combating pollution and environmental conservation. ${ }^{27}$

Attending UNCHE and the processes that preceded and followed it, however, was not quite the same as fully participating in it. And in this regard it seems, at least to some extent, that South African involvement in UN-organised international environmental initiatives fell victim to the prevailing diplomatic strategy of the Department of Foreign Affairs of deliberately keeping a low profile and not drawing unwanted attention to the country and its apartheid policies. This is presumably what was meant by the cryptic reference that problems will be handled according to the 'diplomatic recipe', should South Africa come under

\footnotetext{
${ }^{24}$ Like many other countries, high levels of especially visible pollution became a state and public concern in South Africa at the end of the 1960s, with special attention directed at water, air, noise, marine, electronic, radio-active and radiation pollution and environmental marring. The government reacted to scientific investigations into the state of pollution in the country by strengthening existing anti-pollution laws (e.g. the Atmospheric Pollution Prevention Action, 1965), and through passing new laws such as the Weather Modification Control Act (1972). See Republic of South Africa, Pollution 1971 (Pretoria 1974) for an assessment of the state of pollution in the country in 1971; M.A. Rabie, South African Environmental Legislation (Pretoria, 1976) for a detailed discussion on South African environmental laws and its implementation; and Steyn, 'Environmental Management in South Africa', for a discussion of the development of governmental environmental management in the 1970s.

${ }^{25}$ Sea pollution by oil was at the time a serious concern for the South African cabinet since six serious oil spills occurred in the shipping lanes between Cape Town and Port Elizabeth between 1968 and 1971, of which the biggest was the Wafra oil spill in 1971. Republic of South Africa, Pollution 1971, 73.

26 SAB, DCD 2422 - 27/3/2, Vol. 2: Secretary for Planning - Minister of Planning, Verenigde Nasie Konferensie oor die Menslike Omgewing in Stockholm: 5 tot 16 Junie 1972, undated, 2-3 (memorandum). It should be noted that the initial lack of cabinet approval did not deter the Departments of Panning and of Foreign Affairs from going ahead and making arrangements for the South African delegation, which process started in November 1971.

${ }^{27}$ SAB, DCD 2422 - 27/3/2, Vol. 2: J.J. Loots, Minister of Planning, 7.3.1972 (press release).
} 
political attack at UNCHE. ${ }^{28}$ P.H.J.J. van Vuuren, the official from the Department of Foreign Affairs who represented South Africa at the Second Committee discussions on UNCHE in February 1972, perhaps spelled it out most clearly in his confidential report to the Secretary for Foreign Affairs:

Our delegation [to UNCHE] should go fully prepared to make a positive, contribution that would be worthy of the most highly developed country in Africa. If circumstances appear to be favourable after arrival of our delegation at the conference the delegation should participate as fully and effectively as circumstances permit. If, on the other hand, the assessment is that it would be better for us not to be too much in evidence we should attend quietly and simply observe the proceedings for we, on our part, would be able to learn much, especially from the other developed countries to be represented there. The issues are important and we should not be kept away by fears of possible political action against us. ${ }^{29}$

The expected political problems materialised even before the conference started when eight African countries issued joint guidelines on 13 April 1972 following closed meetings in Dakar to devise a 'joint African stand' to be taken at UNCHE. The Dakar meeting guidelines insisted, inter alia, that the Declaration on the Human Environment should 'denounce unequivocally the crimes committed against mankind and the human development in Africa by the champions of apartheid and their allies'. ${ }^{30}$ This statement merely confirmed the belief of the Department of Foreign Affairs that political matters, i.e. anti-apartheid attacks, would intrude on what they regarded as the technical and scientific matter of the environment at UNCHE. ${ }^{31}$ In direct reference to the Dakar statement and the possibility of political attacks on the country at UNCHE, Fourie stated in a letter to Rautenbach that 'this aspect will be dealt with in the directive which the Department is drawing up for our delegation to Stockholm'. ${ }^{32}$

Unfortunately both the Foreign Affairs directive and Rautenbach's report on UNCHE are not in the archives, despite references to both in other documents. However, judging from the

\footnotetext{
${ }^{28}$ SAB, DCD 2422 - 27/3/2, Vol. 1: J.L. Botha, Department of Planning, 12.5.1971 (memorandum). This is a short summary of the discussions held between Botha and two high-ranking members of the Department of Foreign Affairs.

${ }^{29}$ SAB, DCD 2422 - 27/3/2, Vol. 2: P.H.J.J. van Vuuren - Secretary for Foreign Affairs, Confidential report on XXVI Session of the United Nations General Assembly: Second Committee Item 47: UN Conference on the Human Environment 7.2.1972.

30 'Ecological Reparations Asked by African Group', New York Times, 14.4.1972.

${ }^{31}$ SAB, DCD 2423 - 27/3/2, Vol. 3: Permanent Representative, Permanent South African Mission to the United Nations - Secretary for Foreign Affairs, 17.4.1972 (letter); DCD 2424 27/3/2, Vol. 3: Secretary for Foreign Affairs - Secretary for Planning, 17.5.1972 (letter); Secretary for Planning - South African Embassies in London, Paris, Lisbon and Brussels, 15.5.1975 (letter).

${ }^{32}$ SAB, DCD 2423 - 27/3/2, Vol. 3: Secretary for Foreign Affairs - Secretary for Planning, 3.5.1972 (letter).
} 
official UNCHE record, contemporary South African newspaper reports and retrospective statements and interviews by Rautenbach, it seems plausible to infer that the Department of Foreign Affairs instructed the South African delegation to keep a low profile and attract as little attention as possible. This meant that the four-man delegation, headed by Rautenbach, became mostly observers as opposed to active participants at Stockholm. Reference to South Africa appears only twice in the official UNCHE records. Firstly, the country entered a reservation on Principle 1 of the Declaration on the Human Environment that condemned all policies promoting apartheid, racial discrimination and any form of colonialism, since it felt that this constituted interference in the domestic affairs of a member state of the UN which was against the Charter of this organisation. Secondly, the country opposed a call for a total ban on commercial whale hunting, which objection in all probability had much more to do with openly showing support to Japan, which at that stage was still a largely uncritical major trading partner of the country, than protecting a rapidly dying whaling industry in South Africa. ${ }^{33}$

Given the attendance of a large number of African delegates at the conference, it was not surprising that the country's apartheid policies did come under attack at UNCHE. This was led by the leader of the Tanzanian delegation, Dr W.K. Chugula, who publicly condemned apartheid, racial and colonial oppression as the 'very core of environmental problems in Africa due to the degradation they cause to human resources by taking away rights of many and thereby bringing benefits to only a minority'. ${ }^{34}$ Even those water development projects that the South African government was very proud of at the time, such as the Cabora Bassa and Kunene Dams, which demonstrated the close scientific, technical and economic cooperation that existed between South Africa and colonial Southern African states, were not spared. Chugula requested the conference to take up a strong stand against these projects

\footnotetext{
${ }^{33}$ United Nations, Report of the United Nations Conference on the Human Environment, Stockholm, 5-16 June 1972, available at: <http://www.unep.org/Documents.Multilingual/Default.asp?DocumentID=97> (accessed 20 July 2011). By 1972 the whaling industry in South Africa was confined to the small whaling station of the Union Whaling Company located in Durban. This closed down in 1975. Before UNCHE, Japan lobbied the members of the International Whaling Commission to oppose a proposal to ban all commercial whaling for 10 years. Instead, Japan proposed a 10 year moratorium on endangered whale stocks. SAD, DCD 2423 - 27/3/2, Vol. 4: Secretary for Foreign Affairs - Secretary for Industries, 22.5.1972 (confidential letter); The Japanese Government's Standpoint on the Proposed Recommendation by the Secretariat, Conference on the Human Environment, the United Nations, [1972].

${ }^{34}$ Dr. W.K. Chugula, the Tanzanian Minister of Economic Affairs and Development Planning, as quoted in W. Rowland, The Plot to Save the World: The Life and Times of the Stockholm Conference on the Human Environment (Vancouver 1973), 52.
} 
'whose purpose is to perpetuate a system of human degradation, discrimination and colonial domination'. ${ }^{35}$

The observer role performed by Rautenbach and the other three delegates at UNCHE was a far cry from the active role that the Department of Planning and environmental and scientific agencies in South Africa had hoped and prepared for. This role was explained away by accusing the developing world of making the environment an emotional and political issue (including an anti-apartheid issue) thereby ignoring the 'humble' approach of the developed world which wanted to address the environment as a technical and scientific issue. ${ }^{36}$ This position ignores probably the most important reason for South Africa's limited performance at UNCHE, namely the Department of Foreign Affairs and cabinet's extreme sensitivity towards global hostility to South Africa and their inability to directly deal with problematic situations. In comparison to the massive opposition to the Springbok rugby sport tours at the time, the attacks on the country at UNCHE were a very, very small affair, yet the outcome of these attacks was perhaps more spectacular in the sense that the country's delegation felt compelled to withdraw from active involvement in the deliberations at the conference. The Springboks, in contrast, were not allowed such hasty retreats and had to endure protests after protests at each game as they desperately tried to finish their rugby tours to Britain (1969/70) and Australia (mid-1971) in very hostile political environments.

$* * *$

In a public address in 1986 on South Africa's role and participation in international environmental conservation, John Wiley, the Minister of Environment Affairs and Tourism, detailed the country's limited involvement in UN-led international environmental governance. As in almost all government publications dealing with environmental matters between 1973 and 1994, UNCHE was given central position and credited with bringing order to environmental conservation in South Africa on a national level by highlighting the uncoordinated nature of conservation efforts in the country. ${ }^{37}$ More importantly, in terms of

\footnotetext{
35 'New Attack on SA by Black State', The Pretoria News, 7.6.1972.

${ }^{36}$ ACA, I 36.7: P.S. Rautenbach, 'Die Internasionale Status van Omgewingsbewaring', 4.9.73, 2 (text of speech).

${ }^{37}$ Rautenbach was the first government official to make this claim in 1973, and it featured consistently in all government addresses as well as justifications for new legislation in the years that followed. The promulgation of the Environmental Conservation Act in 1982 was seen to some extent as the logical outcome of the process of rethinking environmental management in the country in light of the UNCHE experience. Ibid., 4-5; J. Wiley,
} 
the focus of this article, is the fact that Wiley, though curiously making no direct reference to UNEP anywhere in the address, blamed the limited participation of the country in UNorganised global environmental initiatives on the isolation of the country in international politics. Referring to the 1982 appraisal conference of UNEP held in Nairobi to assess the progress (or lack thereof) made since UNCHE, Wiley noted that 'South Africa was of course refused attendance'. ${ }^{38}$

The archival records for the 1970s, however, do not support the general claim by Wiley that South Africa was isolated within UN-organised global environmental governance. It further contradicts claims by the UN that the country had been effectively excluded from all UN agencies by 1975, and the position of the limited historiography on this process that the country was isolated within UNEP. These records show that until at least 1980, when UNEP and most files dealing with UN-organised international environmental management disappear completely from the available governmental archival records, South Africa was not deliberately isolated within UN-organised international environmental initiatives in general, and UNEP processes in particular. The problem was rather the South African government and its querulous and unyielding behaviour in reaction to all things that concerned the UN, as well as its foreign policy that continued to place priority on not provoking confrontation in the international political arena. In terms of the environment, avoiding confrontation on the international stage was rather narrowly interpreted from 1975 onwards as merely attending UNEP meetings and most international environmental conferences organised by UN agencies. By then, the cabinet decision of 26 February 1975, which banned the country's participation in the activities of the UN and its agencies, was offered as the standard reason why the Department of Foreign Affairs refused the Department of Planning and the Environment the permission to publicly participate in most UNEP meetings as well as many other UN-organised international environmental conferences and conventions. This cabinet decision was taken in the wake of the suspension of the country from the UN General Assembly on 12 November 1974 and the unsuccessful attempt to have the country expelled

Suid-Afrika se Rol en Betrokkenheid by Internasionale Omgewingsbewaring (C.R. Swart Lecture 19, University of the Orange Free State, Bloemfontein, 5.9.1986), 4-5.

${ }^{38}$ Wiley, Suid-Afrika se Rol en Betrokkenheid, 5. What is referred to in the South African literature as the 1982 appraisal conference, was the $10^{\text {th }}$ session and session of a special character of the Governing Council of UNEP that was held in Nairobi from 10-18 May 1982. See UNEP, Report of the Governing Council (Session of a Special Character and Tenth Session), New York UN, 1982, General Assembly Supplement no. 25(A/37/25), available

at: <http://www.unep.org/resources/gov/prev_docs/82_05_GC10_\%20special_character_report_of_the_GC_10_19 82.pdf> (accessed 20 July 2011). 
from the UN the month before. This cabinet decision in essence meant that the government chose to isolate itself in relation to the UN from 1975 onwards, a couple of years before real global isolation started in earnest following the passing of the mandatory arms embargo by the UN Security Council in November 1977. ${ }^{39}$

It may well be that South Africa was not invited to participate in the special session of UNEP's Governing Council in 1982 to assess the progress made since UNCHE; in the absence of documentary evidence it is not possible to show the contrary. But what is known and documented is the fact that the country was invited to participate in almost all UNEP activities up till 1980. From the documentary sources it is evident that UNEP found South Africa's participation in their activities far less problematic than vice versa. Though the country was not invited to become a member of the 54-member Governing Council, it was invited to the annual sessions of this Council between 1973 and 1980, with the exception of 1975 (when it was generally assumed that the invitation was lost in the post as many items of UNEP correspondence reputedly were at the time), ${ }^{40}$ and the country was further invited to attend the newly instituted inter-sessional informal consultations which were started in 1977. While observers from the Palestine Liberation Organization (PLO) and the Pan Africanist Congress of Azania (i.e. South Africa) started to attend Governing Council meetings from 1975 onwards, UNEP consistently issued invitations to the South African government between 1973 and 1980 to all their activities, with one exception, namely those organised by them under the auspices of the UN Economic Commission for Africa (ECA) owing to the fact that the country had been expelled from the ECA. ${ }^{41}$

South Africa's involvement in UNEP, on the other hand, posed a problem for the Department of Foreign Affairs from the outset. Nairobi, where the organisation was headquartered, was far from a popular choice for the South African government and even the optimistic Rautenbach showed clear signs of weary resignation to this fact when he remarked in a letter to Fourie that 'it [that UNEP will be situated in Nairobi] is now a fait accompli and we simply

\footnotetext{
39 SAB, DCD 2496 - 27/13/2, Vol. 5: Secretary for Foreign Affairs - Secretary for Planning and the Environment, 25.3.1976 (letter).

${ }^{40}$ SAB, DCD 2494 - 27/13/2, Vol. 4: H.F. - Secretary for Planning and the Environment, Attendance of $3^{\text {rd }}$ meeting of the UNEP Governing Council, 18.4.1975 (memorandum).

${ }^{41}$ See contents of the following SAB files: DCD $2492-27 / 13 / 2$, Vol. 1; DCD $2493-27 / 13 / 2$, Vol. 2; DCD 2493 - 27/13/2, Vol. 3; DCD 2494 - 27/13/2, Vol. 4; DCD 2494 - 27/13/2, Vol. 5; DCD 2496 - 27/13/2, Vol. 6; DCD 2497 - 27/13/2, Vol. 7; DCD - 2498 27/13/2, Vol. 9. See also DCD 2497 - 27/13/1, Vol. 7: Secretary for Planning and the Environment - C.A. Quintana, UNEP, 28.6.1978 (letter); C.A. Quintana, UNEP Secretary for Planning and the Environment, 15.6.1978 (letter).
} 
have to make the most of the situation'. ${ }^{42}$ However, while he acknowledged that this would pose certain problems, Rautenbach believed that it would not greatly impede South African participation in UNEP since most of the contact would occur by means of written correspondence and answers to questionnaires, which he was confident would still allow the country the opportunity to make a scientific contribution to the various UNEP programmes. ${ }^{43}$ Fourie, however, was much more cautious than Rautenbach and suggested that the decision regarding South Africa's participation in UNEP be postponed until a later date when they had greater certainty on whether the country would be allowed to participate in the new UN agency. Only then could the decision be taken on whether the country would want to become involved in UNEP. ${ }^{44}$

The Department of Planning and the Environment (as the department was known from February 1973) did not quite agree with Foreign Affairs' 'wait and see' attitude, and dispatched the head of the newly created division of Environmental Conservation, Mr J.J. le Grange, to Europe in June 1973 to attend the first meeting of UNEP's Governing Council which was held in Geneva in the same month. Le Grange reported very favourably on the meeting and UNEP, and held the belief that there were a number of areas such as energy and the International Referral Service for Sources of Environmental Information (hereafter IRS) where the country could make valuable contributions. He also recommended that the country consider contributing to the Environmental Fund and participating in the conference on Human Settlements that would be held in Vancouver in 1976, and make a decision on how to deal with World Environment Day (5 June). ${ }^{45}$ Enthusiasm for UNEP within the Department of Planning and the Environment diminished markedly, though also only temporarily, by June 1974, with Le Grange expressing his opinion at an interdepartmental meeting with Foreign Affairs on the country's participation in UNEP that the country 'did not derive any

${ }^{42}$ SAB, DCD 2424 - 27/3/2, Vol. 5: Secretary for Planning and the Environment - Secretary for Foreign Affairs, 16.3.1973 (letter).

${ }^{43}$ Ibid.

${ }^{44}$ SAB, DCD 2424 - 27/3/2, Vol. 5: Secretary for Foreign Affairs - Secretary for Planning and the Environment, 22.3.1973 (letter).

${ }^{45}$ SAB, DCD 2492 - 27/13/2, Vol. 1: J.J. le Grange, Verslag oor Bywoning van die Eerste Vergadering van die Beheerraad (E. Governing Council) van die Verenigde Nasies se Omgewingsprogram (E. United Nations Environment Programme) Gehou te Genéva op 12 tot 22 Junie 1973, 22.10 .1973 (report); Secretary for Planning and the Environment - Secretary for Foreign Affairs, 2.11.1973 (letter). The South African Committee on Environmental Conservation (created in 1972) already recommended on 19 April 1973 that the South African government honour the global call to designate 5 June as World Environment Day. Cabinet reacted positively to this recommendation and the first World Environment Day was celebrated in the country in 1973, and continued to be celebrated annually in the following years. As was the case in many other countries, 5 June was not designated as a public holiday in South Africa which meant that its profile was rather limited with the general public apart from in schools where most of the activities were concentrated. 
advantages from UNEP'. ${ }^{46}$ Though nowhere stated as such, in all probability his negative views resulted from the experiences of the South African delegates to the Global Environmental Monitoring System meeting (Nairobi, February 1974), and at the second session of the Governing Council (Nairobi, 11-22 March 1974), both of which were attended by La Grange and H.J. Grové. At the latter meeting, Zaire first tried to have the country excluded, and having failed in this, raised the problem of apartheid and attempted to have this policy designated as a 'pollutant'. ${ }^{47}$ Ironically, at the interdepartmental meeting at least, it was the leader of the Foreign Affairs delegation, Mr W.S. van Heerden, who came out in favour of continuing the country's participation in UNEP, stating that

at the Stockholm Conference in 1972 the opinion was expressed that the time had come for the world to tackle the growing problem of pollution...South Africa must adopt the attitude that as we are part of the world we ought to do something about pollution as well. We must not have a negative approach to this and anything we can do can only benefit us in the long run if it helps make the world a better place for all to live in. Leaving UNEP would certainly not be any advantage to us. ${ }^{48}$

In the end that decision was not up to officials in the Department of Planning and the Environment, and lesser officials in Foreign Affairs. The cabinet decision of 26 February 1975 effectively brought South Africa's public participation in UNEP to an end, starting with their refusal to grant the Department of Planning and the Environment permission to attend the third session of the Governing Council of UNEP held in Nairobi from 17 April - 2 May 1975. After February 1975 the country only once attended a public meeting of UNEP, namely the first inter-sessional informal consultation that was held in Geneva from 17-19 January 1977. ${ }^{49}$ The true meaning of the cabinet decision, however, did not seem to have registered with those dealing with UNEP in the Department of Planning and the Environment, nor with the department's new secretary, Mr J.F. Otto, who replaced Rautenbach in February 1976. Every invitation the department received from UNEP between 1975 and 1980 was seriously considered, opinions were solicited from interested parties (i.e. other government departments and state and private scientific bodies dealing with the specific

\footnotetext{
${ }^{46}$ SAB, DCD 2493 - 27/13/2, Vol. 3: Summary of Discussions Held on the Morning of Tuesday 16 July 1974 Between Representatives of the Departments of Planning and the Environment and Foreign Affairs on the Subject of the United Nations Environment Programme, 1.

${ }^{47}$ Ibid., 1, 4-5. See also UNEP, Report of the Governing Council on the Work of its Second Session, 11-22 March 1974, UN Supplement nr. 25 (A/9625), available at: <http://www.unep.org/resources/gov/prev_docs/74_05_GC2_report_K7409625.pdf> (accessed 20 July 2011).

48 SAB, DCD 2493 - 27/13/2, Vol. 3: Summary of Discussions Held on the Morning of Tuesday 16 July 1974 Between Representatives of the Departments of Planning and the Environment and Foreign Affairs on the Subject of the United Nations Environment Programme, 2.

49 SAB, DCD 2497 - 27/13/2, Vol. 7: F.D. Tothill, Permanent Representative, South African Permanent Mission, Geneva - Secretary for Foreign Affairs, 26.1.1977 (report).
} 
environmental issues at hand), and more often than not delegates identified who should represent the country, only for the department to be informed by Foreign Affairs that the cabinet decision of 26 February 1975 was still in force. Fourie, for example, refused the South African delegation to the $4^{\text {th }}$ session of UNEP's Governing Council permission to go only five days before the start of the session on 30 March 1976 on the basis that the country 'must avoid any possible confrontation that might develop'. ${ }^{50}$ Similar requests to attend the Governing Council meetings in 1977, 1978, 1979 and 1980 were refused with reference to the cabinet decision, as were requests to attend the inter-sessional informal consultations in 1978 and 1979. The cabinet decision did not deter Rautenbach, in his final months as Secretary for Planning and the Environment, from requesting in September 1975 that the Department of Foreign Affairs officially consider setting up a permanent mission to UNEP in Nairobi, which in his view would provide the country with an excellent opportunity to further the country's interests not only in environmental matters but also political matters. This request, not surprisingly, did not find favour within Foreign Affairs, with Fourie replying that since the country was at a cross-road in terms of its relationship with the UN, no decision could be made with regard to UNEP before the relationship with the UN was sorted out. ${ }^{51}$

The Department of Foreign Affairs also put a halt to South Africa's contribution to UNEP's Environmental Fund in 1975. While the country's reaction was rather lukewarm to the original American proposal in 1972 to set up an Environmental Fund, the idea slowly gained popularity within government circles in 1973, with both La Grange and the South African Committee on Environmental Conservation proposing that the country contribute to this Fund. ${ }^{52}$ A definite decision in this regard was only taken in July 1974 when it was decided at an interdepartmental meeting between Foreign Affairs and Planning and the Environment that the country would make a contribution of R250,000 (then valued at around US $\$ 375,000$ ) that was to be spread out over five years. This contribution was motivated by two considerations, namely the concrete scientific benefits that stemmed from South Africa's participation in UNEP, and the fact that the country's position in the Southern African

\footnotetext{
${ }^{50}$ SAB, DCD 2496 - 27/13/2, Vol. 5: Note in file by J.J. le Grange, 25.3.1976.

51 SAB, DCD 2494 - 27/13/2, Vol. 4: Secretary for Planning and the Environment - Secretary for Foreign Affairs, 17.9.1975 (letter); Secretary for Foreign Affairs - Secretary for Planning and the Environment, 2.10.1975 (letter).

52 SAB, DCD 2423 - 27/3/2, Vol. 4: Ambassador, Embassy of South Africa, Washington, D.C. - Secretary for Foreign Affairs, 12.5.1972 (confidential letter).
} 
Regional Commission for the Conservation and Utilisation of the Soil (SARCCUS) ${ }^{53}$ might be weakened if other member states decided to make a contribution to the Environmental Fund and South Africa did not. An application was duly submitted to the Treasury in this regard in October 1974. However, by then the relationship between South Africa and the UN had taken a turn for the worse, and by December 1974 Rautenbach informed the Treasury that Foreign Affairs had instructed the Department of Planning and the Environment to hold back the R50,000 contribution for 1975 for six months. Since the country's relationship with the UN did not improve after 1975, South Africa did not make any contributions to UNEP during the apartheid era. ${ }^{54}$

The South African cabinet's ban on the country's public participation in UN and UN-related activities did not extend to technical and scientific co-operation with UNEP. Following a written request in June 1976 from the newly appointed Secretary for Planning and the Environment, J.F. Otto, for clarification of whether the department was still allowed to cooperate with UNEP on scientific matters, Fourie responded in November 1976 stating that Foreign Affairs had no problem if the department continued to provide information to this UN organisation. ${ }^{55}$ By then the Department of Planning and the Environment had already acted as the central point for all UNEP enquiries for three years, and had actively contributed

\footnotetext{
${ }^{53}$ SARCCUS was inaugurated in 1950 to focus attention on the problems involved in the conservation and utilisation of natural resources, and to provide mechanisms for the exchange of information to successfully address these problems. It was transformed into an autonomous regional commission in 1964 and continued to exist until at least 2000 when references to it disappear from the electronic record. Despite SARCUSS' refusal to allow political matters to intrude on its operations, and its sole focus on technical and scientific aspects throughout the apartheid era, several countries starting with Zambia in 1964 left after becoming independent. By 1974 membership was confined to Angola, Botswana, Lesotho, Malawi, Mozambique, South Africa, South West Africa and Swaziland. Malawi was the sole member with a seat on UNEP's Governing Council in the 1970s. Angola and Mozambique left after they obtained independence in 1975. A rival organisation, the Southern Africa Centre for Cooperation on Agricultural Research (SACCAR) was set up in 1984 by the Southern African frontline states, and became an official commission of the Southern African Development Coordinating Conference (which transformed into the Southern Africa Development Commission in 1992). M.J. Botha, 'Institutional Co-Operation to Address Socio-Economic Aspects Relating to Migrant Pests of Agriculture in the Southern African Region", R. A. Cheke, L. J. Rosenberg and M. E. Kieser (eds), Workshop on Research Priorities for Migrant Pests of Agriculture in Southern Africa, Plant Protection Research Institute, Pretoria, South Africa, 24-26 March 1999 (Chatham 2000), 59-64, available at: <http://icosamp.ecoport.org/archives/mpw/P06.pdf> (accessed 22 July 2011); Amos Jenkins Peaslee, International Governmental Organizations: Constitutional Documents ( $3^{\text {rd }}$ edition, Parts 3 and 4, The Hague, 1979), 423-4. See also the website of the SADC available at: http://www.sadc.int

${ }^{54}$ SAB, DCD 2493 - 27/13/2, Vol. 3: Summary of Discussions Held on the Morning of Tuesday 16 July 1974 Between Representatives of the Departments of Planning and the Environment and Foreign Affairs on the Subject of the United Nations Environment Programme, 3-4; Secretary for Planning and the Environment Secretary for the Treasury, 23.10.1974 (letter); DCD 2496 - 27/13/2, Vol. 6: Secretary for Foreign Affairs Secretary for Planning and the Environment, 5.11.1976 (letter).

${ }^{55}$ SAB, DCD 2496 - 27/13/2, Vol. 5: Secretary for Planning and the Environment - Secretary for Foreign Affairs, 2.6.1976 (letter); DCD 2496 - 27/13/2, Vol. 6: Secretary for Foreign Affairs - Secretary for Planning and the Environment, 5.11.1976 (confidential letter).
} 
to the development of the Global Environmental Monitoring System, and the IRS. The department continued with the provision of national technical and scientific data to UNEP, at least until 1980 when documentary evidence ceases in the governmental archives, on a plethora of environmental issue ranging from weather modification systems, environmental administration, environmental education, the manufacturing of chlorofluorocarbons F-11 and F-12, water pollution, the environmental aspects of non-ferrous metals, to desertification in the country. ${ }^{56}$ And, judging from the documents consulted, UNEP did incorporate the South African data into their numerous publications without prejudice. The 1975 UNEP report Activities Related to the Priority Subject Area Land, Water and Desertification, for example, gave prominence to the South African activities and, as one 'H.F.' pointed out rather excitedly to Rautenbach, 'devoted as much space to South Africa as for example to the United Kingdom'. ${ }^{57}$

The one focus area of UNEP, and also the main focus area of the organisation in its initial years, that failed to arouse the interest of both the Departments of Planning and the Environment, and of Foreign Affairs, was that of human settlements. None of the South African government departments shared UNEP's view that human settlements and the need to provide families with housing constituted an environmental problem. Rather, within the South African context this was viewed as a socio-economic and race issue, that should be addressed through proper planning and segregation measures. As a result, unlike the Environmental Fund, South Africa never contemplated making a financial contribution to the International Habitat and Human Settlement Foundation (established in 1974) during the apartheid era. ${ }^{58}$ Of all the environmental issues that featured on an international level in the 1970s, human settlements were the one issue where South African diplomats and civil servants showed their blind commitment to the apartheid policy. And they were in general seemingly incapable of realising just how offensive the practical implementation of these

\footnotetext{
${ }^{56}$ See, for example, SAB, DCD 2493 - 27/13/2, Vol. 2: Data on National Activities Undertaken by the Republic of South Africa Regarding Land, Water and Desertification, [1974]; DCD 2493 27/13/2, Vol. 3: Framework for Information on Environmental Activities: South African Submission to UNEP, November 1974; DCD 2497 27/13/2, Vol. 7: Secretary for Planning and the Environment - Executive Director, UNEP, 21.7.1977 (letter); Secretary for Industries - Secretary for Environmental Planning and the Environment, 15.11.1979 (letter); DCD 2498 - 27/13/2, Vol. 9: Acting Secretary for Environmental Planning and Energy - Executive Director, UNEP, 16.7.1979 (letter); Secretary for Mines - Secretary for Environmental Planning and Energy, 20.11.1979 (letter). ${ }^{57}$ SAB, DCD 2494 - 27/13/2, Vol. 4: H.F. - Secretary of Planning and the Environment, Acknowledgement of South Africa in UNEP Documents, 2.4.1975 (memorandum).

${ }^{58}$ SAB, DCD 2493 - 27/13/2, Vol. 3: Summary of Discussions Held on the Morning of Tuesday 16 July 1974 Between Representatives of the Departments of Planning and the Environment and Foreign Affairs on the Subject of the United Nations Environment Programme, 4.
} 
policies was to the global political community, despite repeatedly acknowledging that apartheid housing and planning policies left the country open to political attacks in the international political arena. The report of the country's Permanent Representative to the UN on the meeting of the Economic Commission for Europe's Committee on Housing, Building and Planning that was held in Geneva in October 1973 is a good case in point. During this session, the Committee dealt with the rehabilitation of slums and squatter settlements and noted the enormous challenge such areas posed for cities in the developing world. The Permanent Representative reported back to Fourie that the analysis of the report of the Committee

lends some indirect support for South Africa's influx control policies and the rationale behind them... If the political obstacles could be overcome there would seem to be little doubt that South Africa could make a positive contribution and render constructive assistance in this area, as indeed in a number of others. $^{59}$

The inability to realise that what the South African government saw as achievements, such as the building of Lilongwe in Malawi, ${ }^{60}$ economic and infrastructural developments in the Bantustans, and separate urban development, were generally not viewed by the global community as something to boast about, was not confined to the Department of Foreign Affairs. The Department of Planning and the Environment, as the key government department involved with apartheid planning and decentralisation, was also incapable of comprehending the level and intensity of global opposition to apartheid's human settlements policies. This was clearly demonstrated when it was decided that the country's exhibition at the UN Conference on Human Settlement (popularly known as Habitat 1976) that was to be held in Vancouver from 31 May - 11 June 1976, would focus on the Transkei, despite mounting international opposition to this region's impending independence from South Africa in October $1976 .{ }^{61}$ The Department argued that such an exhibition

\footnotetext{
${ }^{59}$ SAB, DCD 2426 - 27/3/3/4, Vol. 2: Permanent Representative, Permanent South African Mission to the UN Secretary for Foreign Affairs, 17.8.1973 (letter).

${ }^{60}$ South Africa planned and built Lilongwe as new capital of Malawi for the country's dictator, Dr Hastings Banda from the late 1960s. It formed part of Prime Minister John Vorster's outward or détente policy, which strove to build relationships with African states from the late 1960s onwards. Banda was one of the few African leaders who responded positively to this policy, much to the dismay of the Organisation of African Unity and other African leaders.

61 See United Nations, United Nations and Apartheid, documents 84-5 for UN responses to Transkei independence on 26 October 1976.
} 
would cover the contrasts of the old and the new as well as things such as growth points and the fact that the Transkei is on the road to Independence... Although the film would be mainly of a technical nature the opportunity should not be lost for a little South African propaganda. ${ }^{62}$

Habitat 1976 was the one environmental event where the Department of Planning and the Environment initiated South Africa's withdrawal from participating before Foreign Affairs could suggest it. In a letter to Fourie dated 17 March 1975, Rautenbach suggested that it was in the best interest of South Africa not to participate in Habitat 1976 owing to the fact that political matters were increasingly intruding on the agenda of the conference/exhibition. All preparations for the country's exhibition were halted in June 1975 and in December Fourie informed Rautenbach that South Africa could not participate in Habitat 1976. The SecretaryGeneral of Habitat 1976 was only informed of this decision on 17 March 1976 with nonspecified 'technical reasons' cited as explanation for the country's decision. ${ }^{63}$ As expected, Habitat 1976 did provide a forum for the anti-apartheid movement to attack South Africa's housing policies. These attacks started already during the preparatory phase when Libya attempted without success at the end of 1975 to have Israel and South Africa formally excluded from the conference/exhibition. ${ }^{64}$ At the conference/exhibition, South Africa came under attack from the representative of the UN Council for Namibia, Kalevi Saarela, who called on the delegates to help the people of Namibia obtain adequate housing by removing the illegal occupation of South Africa; the ANC representative, Sindiso Mfenyana, who attacked the sale of French nuclear reactors to the country and accused the South African government of showing that it 'was a willing instrument to recolonize independent Africa' ${ }^{165}$ through its military intervention in Angola, and the PAC representative, Mokalake Elias Ntloedibe, who criticized multi-national company involvement in the country. ${ }^{66}$

\footnotetext{
62 SAB, DCD 2493 - 27/13/2, Vol. 3: Summary of Discussions Held on the Morning of Tuesday 16 July 1974 Between Representatives of the Departments of Planning and the Environment and Foreign Affairs on the Subject of the United Nations Environment Programme, 5-6.

${ }^{63}$ SAB, DCD 2500 - 27/13/3/2, Vol. 2: Secretary for Planning and the Environment - Secretary for Foreign Affairs, 17.3.1975 (letter); Secretary for Planning and the Environment - J.J. la Grange, Chair of the Launch Committee, 12.5.1975 (letter); Unsigned note in file dated 13.6.1975; SAB, DCD 2501 - 27/13/3/2, Vol. 4: Note in file re telephone conversation with Mr Van Niekerk, Department of Foreign Affairs re Vancouver Conference, 18.12.1975.

${ }^{64}$ SAB, DCD 2501 - 27/13/3/2, Vol. 4: D.O. Gericke, Permanent South African Mission to the United Nations - Secretary for Foreign Affairs, 22.9.1975 (letter).

${ }^{65}$ SAB, DCD 2502 - 27/13/2, Vol. 6: South African Embassy, Ottowa - Secretary for Foreign Affairs, Submission re Habitat Conference, 31 May - 11 June 1976, 16.6.1976.

${ }^{66} \mathrm{Ibid}$.
} 
According to the limited historiography, apartheid South Africa was not interested in any environment-related international conventions that could in any way place limitations on the country's economic growth and development, and only participated in those international initiatives that dealt with fauna and flora conservation since it did not entail paying constructive attention to new environmental issues such as pollution. ${ }^{67}$ The archival records, however, do not support this view, and the answer as to why the country did not participate in conventions and conferences on the ozone layer, mycotoxins, desertification, technical cooperation among developing countries, and the legal aspects of weather modification in the 1970s can be found in the country's difficult relationship with the UN and UN agencies at the time. Invitations for all these events were issued to South Africa (in excess of 10 invitations), but in most cases the Department of Foreign Affairs ruled out the country's participation during the planning phases. A Mr Stroebel in Foreign Affairs, for example, said that the country should not participate in the joint FAO/WHO/UNEP Conference on Mycotoxins (Nairobi, 19-27 September 1977) since it was co-organised by the FAO and the WHO, which in turn meant that the country, which was expelled from both UN specialist agencies in the 1960s, would not be allowed to attend despite the invitation. ${ }^{68}$ Fourie also ruled out the country's attendance at the UN Conference on Technical Co-operation Among Developing Countries (Buenos Aires, 30 August - 12 September 1978) in a terse letter to the Secretary of Planning and the Environment, while the Secretary of Water Affairs pointed out that the country would not be welcome at the joint WHO/UNEP meeting of experts on the legal aspects of weather modification (Geneva, 17-21 September 1979) because of WHO's involvement. This was, in his view, regrettable since South Africa was able to make valuable contributions in this field and would also be able to learn from other countries. ${ }^{69}$

The UN Conference on Desertification (New York, 29 August - 9 September 1977) is the one exception to this trend: South Africa's attendance was ruled out not by Foreign Affairs, but by both the Department of Agricultural Technical Services and the Council for Scientific and Industrial Research (CSIR), the two main bodies concerned with desertification in the

\footnotetext{
${ }^{67}$ Phia Steyn, 'Environmental Management in South Africa'.

${ }^{68}$ SAB, DCD 2497 - 27/13/2, Vol. 7: Note (10.6.1977) on UN letter: Joint FAO/WHO/UNEP Conference on Mycotoxins, Nairobi, 19-27 September 1977, 27.5.1977.

69 SAB, DCD 2427 - 27/4/2, Vol. 1: Secretary for Foreign Affairs - Secretary for Planning and the Environment, 20.6.1978 (letter); SAB, DCD 2497 - 27/13/2, Vol. 7: Secretary for Environmental Planning and Energy - Secretary for Water Affairs, 5.4.1979 (letter); Secretary for Water Affairs - Secretary for Environmental Planning and Energy, 12.4.1979 (letter).
} 
country, after the Secretary for Planning and the Environment solicited their views on whether the country should attend and who should be delegated as representatives. The Department of Agricultural Services offered no explanation for their decision beyond stating that they did not regard it desirable that this conference be attended. The CSIR, on the other hand, felt that the contributions required from the country were not purely technical and scientific, and Dr Noble therefore felt that it was not necessary for scientists to attend the conference. Foreign Affairs' views are unfortunately not contained within the documents consulted, but given their official policy of avoiding all possible confrontation on the international political stage, they no doubt were rather relieved that South Africa did not participate in this conference after reading the report on the conference that contained two resolutions (condemning the country's rule over South West Africa and the Bantu homeland policy) adopted against the country. ${ }^{70}$

This stands in sharp contrast to the country's participation in international environmental initiatives in the 1970s (and continuing into the 1980s) that fell outside UN control, and which concerned themselves mostly with technical, scientific and policy issues, and did not allow political matters to be incorporated onto agendas. Pooley, Carruthers, Beinart, Van der Watt, Dubow and others have all documented the active participation of South Africa and its scientists in a variety of global environmental initiatives ranging from forestry, fynbos, soil, marine and nature conservation, wildlife management, conservation biology, pollution control, climate to Antarctica. ${ }^{71}$ This included the 1973 Convention on International Trade in Endangered Species of Wild Fauna and Flora (CITES). The country was not only allowed to actively participate in all CITES convention party meetings, but was in general warmly received (as noted consistently in all consulted documents) by all parties, and the secretariat negotiated the friendly reception of the South African delegation even by governments hostile

\footnotetext{
70 SAB, DCD 2497 - 27/13/2, Vol. 7: Secretary for Planning and the Environment - Dr. Noble, CSIR, 30.6.1977 (letter); Secretary for Agricultural Technical Services - Secretary for Planning and the Environment, 12.7.1977 (letter); Note of 19.7.1977 on letter from Permanent South African Mission to the United Nations Secretary for Foreign Affairs, 16.9.1977.

71 See, for example, Simon Pooley, 'Recovering the Lost History of fire in South Africa's Fynbos', Environmental History, 17, 1 (Jan 1972), 55-83; Jane Carruthers, "'Wilding the Farm or Farming the Wild"? The Evolution of Scientific Game Ranching in South Africa from the 1960s to the Present', Transactions of the Royal Society of South Africa, 63, 2 (2008), 160-181; William Beinart, The Rise of Conservation in South Africa: Settlers, Livestock, and the Environment 1770-1950 (Oxford, 2003); Lize-Marié van der Watt, 'Return to Gondwanaland: South Africa, Antarctica, Minerals and Apartheid', The Polar Journal, 3, 1 (2013), 72-93; Dubow, A Commonwealth of Knowledge. For a government perspective, see Wiley, Suid-Afrika se Rol en Betrokkenheid.
} 
to apartheid, as was the case with Costa Rica in $1979 .{ }^{72}$ Within the context of the strained relationship between the country and the UN, it is not surprising that South Africa was a strong ally of Britain in the campaign in the mid-1970s to resist the extension of UNEP control over the Antarctic Treaty. ${ }^{73}$ Given the real political isolation of the country on an international level by the late 1970s and 1980s, these few opportunities for the country to cooperate 'normally' with other global actors became very important to the South African government, both for their obvious scientific benefit but also for propaganda reasons. ${ }^{74}$ In the course of the 1980s these few areas in which the country was able to operate internationally were consistently used in government propaganda as 'evidence' that the country was still an international player and not the 'abnormal society' that most of the world had come to oppose. $^{75}$

$$
* * *
$$

This analysis of apartheid South Africa's participation in UN-organised international environmental governance in the 1970s reveals the importance of exploring the interdepartmental relations and politicking in order to provide a more comprehensive understanding of the country's lacklustre performance in UN-led international environmental management and governance in this decade. By contrast to the limited historiography on this topic, this article has argued that the reasons for the country's limited participation on the UN-dominated international stage where the environment was concerned are not to be found in the perceived lack of commitment to the environment by the NP government in the 1970s and the isolation of the country on an international level. Rather, it resulted firstly from the unyielding behaviour of the South African government in all things that concerned the UN. The mere fact that the vast majority of the international environmental initiatives in the 1970s were organised by the UN and its agencies, meant that the South African government was

\footnotetext{
72 See, for example, SAB, DCD 2513 - 27/17/2, Vol. 1: J.S.F. Botha, South African Embassy, Washington, D.C. - Secretary for Foreign Affairs, 26.3 .1973 (letter); SAB, DCD 2513 - 27/22/3/1, Appendix: Verslag oor die Bywoning van die Spesiale Werksessie oor die Konvensie oor Internasionale Handel in Bedreigde Fauna and Flora Spesies, 17 tot 20 Oktober 1997, Genéve (report). See also contents of file SAB, DCD $2513-$ 27/22/2, Vol. 1: Environmental Conservation. International Conventions Relating to the Environment.

73 SAB, DCD 2494 - 27/13/2, Vol. 4: South African Ambassador, London - Secretary for Foreign Affairs, 29.4.1975 (confidential letter); 'South Africa Should Stay in the I.W.C.', African Wildlife, 37, 5 (1983), 174-75.

${ }^{74}$ This was especially true in terms of the country's image on the international stage. The Department of Planning and the Environment, for example, was keen that the country signed the Convention on the Prohibition of Military and Other Hostile Use of Environmental Modifications Techniques in 1977 mainly because it would signify the country's 'concern for the conservation of the environment even in a state of warfare'. DCD 2427 27/4/2, Vol 1: Secretary for Planning and the Environment - Secretary for Foreign Affairs, 29.6.1977 (letter).

${ }^{75}$ See, for example, Wiley, Suid-Afrika se Rol en Betrokkenheid.
} 
negatively predisposed to these initiatives from the outset, regardless of the importance the government attached to environmental issues on a national and an international stage. This situation was complicated by a second factor, namely the prevailing foreign policy of the government that dictated that the country should avoid all possible confrontations and should not draw unwanted attention to itself and its apartheid policies, even if it meant self-isolation. This self-isolation, and not the exclusion of the country by the UN, as was claimed by Wiley and many other government officials, was one of the main reasons for South Africa's undistinguished performance in UN-led global environmental initiatives in the second half of the 1970s. The one aspect of the existing historiography that still holds true is the fact that the South African government was unable and unwilling to view the environment as a political issue in the 1970s, and this continued to be the case right till the very end of National Party rule in 1994. The reason for that is perhaps rather simple: because of the activities of the antiapartheid movement and its successes in politicising sport and culture in the late 1960s and early 1970s, the apartheid government had come to equate 'political' attacks with 'antiapartheid' attacks. Acknowledging that the environment was a political issue, would therefore have opened the country up to anti-apartheid attacks on a whole new front, which the government was simply unwilling to contemplate. ${ }^{76}$

\section{Acknowledgements}

Many thanks to Ben Marsh, Robin Law and Sharla Chittick for commenting on the draft manuscript, and Catherine Mills for her assistance. I am further grateful for the comments of the anonymous reviewers which aided me greatly in clarifying and strengthening my thoughts and arguments.

\section{Funding}

This work was supported by a Small Research Grant from The Carnegie Trust for the Universities of Scotland.

\footnotetext{
${ }^{76}$ One should point out that the Anti-Apartheid Movement was also slow to incorporate the environment into the anti-apartheid agenda. They had to be convinced by Earthlife Africa in 1988 that the environmental agenda offered the opportunity to address pertinent issues associated with apartheid. See Steyn and Wessels, 'The Emergence of New Environmentalism in South Africa, 1988-1992' for more details.
} 